\title{
Seed treatment affects Meloidogyne incognita penetration, colonization and reproduction on cotton
}

\author{
Tratamento de sementes afeta a penetração, colonização e reprodução de Meloidogyne incognita \\ em algodão
}

Rosana Bessi $^{{ }^{*}}$ Fernando Ribeiro Sujimoto $^{\mathrm{I}}$ Mário Massayuki Inomoto ${ }^{\mathrm{I}}$

-NOTE -

\section{ABSTRACT}

The effect of abamectin, applied as seed treatment, on Meloidogyne incognita penetration, colonization, and reproduction on cotton was evaluated in two greenhouse experiments. Second stage juveniles (J2) penetration was evaluated 3, 9 and 15 days after germination (dag), whereas the nematode colonization was evaluated $27 \mathrm{dag}$, by counting the total number of galls and egg masses per root system. Eggs and J2 were extracted from the roots to assess the nematode reproduction at 50 and 100dag. The seed treatment caused a decrease in $\mathrm{J} 2$ penetration in the roots, resulting in lower colonization and reproduction of $\boldsymbol{M}$. incognita. These findings are discussed considering the environmental aspects of abamectin in the soil and the current practices for the crop management.
\end{abstract}

Key words: abamectin, Gossypium hirsutum, knot-root nematode, nematicide.

\section{RESUMO}

O efeito de abamectina em tratamento de sementes na penetração, colonização e reprodução de Meloidogyne incognita, em algodão, foi avaliado em dois experimentos de casa de vegetação. A penetração de juvenis de segundo estádio (J2) foi avaliada aos três, nove e 15 dias após a germinação (dag), enquanto que a colonização $27 \mathrm{dag}$ foi avaliada por meio da contagem do número total de galhas e massas de ovos por sistema radicular. Ovos e J2 de M. incognita foram extraídos das raízes para determinar a reprodução do nematoide aos 50 e 100dag. O tratamento de sementes diminuiu a penetração dos J2 nas raízes, resultando em menor colonização e reprodução de $\mathbf{M}$. incognita. Os resultados obtidos são discutidos tendo em vista os aspectos ambientais da presença de abamectina no solo e as práticas agrícolas em uso.

Palavras-chave: abamectina, Gossypium hirsutum, nematoide das galhas, nematicida.
The root-knot nematode [Meloidogyne incognita (Kofoid and White)] is the most threatening species in cotton production, mainly in areas with coarse-texture soils (MONFORT et al., 2007). Nowadays, it is widespread in Brazilian cotton plantations in Bahia, Goiás, Paraná and São Paulo states, causing yield losses that range from 10 to $40 \%$ (ASMUS \& INOMOTO, 2007). Crop rotation is the most effective measure for the management of M. incognita in cotton although its application, in Brazil and the United States, is sometimes restrict by the low number of non-hosts available for use, such as peanut (Arachis hypogaea) and brachiaria grasses (Brachiaria spp.) (ASMUS \& INOMOTO, 2007; STARR et al., 2007). Also, genetic resistance is of limited value due to the low availability of high yielding nematode-resistant cultivars (STARR et al., 2007). As a consequence of the constrained utilization of crop rotation and cotton resistant cultivars, the application of granular nematicides, as aldicarb, carbofuran and terbuphos, in the planting furrow is yet widely used, in spite of their elevated costs in comparison to the modest results in terms of yield increase (120 to $180 \mathrm{~kg}$ of cotton lint) (ASMUS \& INOMOTO, 2007).

An abamectin formulation (Avicta) was recently available as a seed treatment for cotton and vegetable crops. Such method is a low-cost treatment, in which abamectin is placed at a close proximity to plant-parasitic nematodes, minimizing some undesirable characteristics of this substance, as low water solubility

'Departamento de Fitopatologia e Nematologia, Escola Superior de Agricultura "Luiz de Queiroz" (ESALQ). Av. Pádua Dias, 11, CP, 9, 13418-900, Piracicaba, SP, Brasil. E-mail: rosbessi@yahoo.com.br. *Autor para correspondência. 
and rapid decomposition in soil (MONFORT et al., 2006). In addition, comparing to the traditional granular nematicides, the use of seed treatment represents significantly lower environmental risk and toxicity to humans. Taking into account the increasing importance of seed treatment for nematode management, two greenhouse experiments were carried out in order to evaluate the effect of cotton seed treatment with abamectin on $\boldsymbol{M}$. incognita penetration, colonization, and reproduction.

Experiment 1. Meloidogyne incognita race 4 was collected from a cotton field in Campo Verde, Mato Grosso state, and maintained alternately on tomato and cotton plants in a greenhouse. Nematodes were extracted from tomato roots using blender and flotation centrifugal technique (COOLEN \& D'HERDE, 1972 ), using $0.5 \% \mathrm{NaOCl}$ and centrifuged at $580 \mathrm{~g}$. The aqueous suspension obtained, containing eggs and juveniles $(\mathrm{J} 2)$, was used as inoculum. Plastic pots $(7.6 \mathrm{~cm}$ high $x 5.5 \mathrm{~cm}$ diam., $\left.180 \mathrm{~cm}^{3}\right)$ were filled with steamtreated sandy clay soil (57\% sand, $4 \%$ silt and $39 \%$ clay, $\mathrm{pH} 6,3,15 \mathrm{~g}$ organic matter $\mathrm{dm}^{-3}$ ), and $1.25 \mathrm{~mL}$ of the inoculum, containing 1,000 freshly extracted specimens (918 eggs and $82 \mathrm{~J} 2$ ), were transferred to a central $2-\mathrm{cm}$ hole in the substrate. The surface was covered with the same substrate and the pots were kept for three days (average temperature: $25^{\circ} \mathrm{C}$ ) to allow the hatching of $\mathrm{J} 2$. After this period, one seed of a susceptible cotton cultivar, Fibermax 966, not treated or treated with abamectin (150 $\mu \mathrm{g}$ of abamectin per seed), both from Syngenta Proteção de Cultivos Ltda. (São Paulo SP, Brazil), was placed in the same central hole as the nematodes. The germination occurred three days after sowing. The infected plantlets were then assigned to evaluate penetration, colonization and reproduction, using 8 replications per date of sampling.

The effect on the J2 penetration was evaluated 3, 9 and 15 days after germination (dag), when treated and non-treated seedlings were removed from the substrate and their root systems gently washed under tap water. The $\mathrm{J} 2$ in the whole root system were then stained using acid fuchsin (DAYKIN \& HUSSEY, 1985) and counted under stereomicroscope. The effect on nematode colonization was evaluated $27 \mathrm{dag}$, by counting the total number of galls and egg masses per root system. For this evaluation, Phloxine B (aqueous solution containing $15 \mathrm{mg} \mathrm{L}^{-1}$ ) was used to stain the egg masses. From the remaining plants, half were transferred to $500-\mathrm{cm}^{3}$ plastic pots $(11.6 \mathrm{~cm}$ high $\times 7.4 \mathrm{~cm}$ diam) containing steam-treated substrate, in order to assess the nematode reproduction at $50 \mathrm{dag}$. The other plants were transferred to $1,500-\mathrm{cm}^{3}$ clay pots for assessing the reproduction at 100dag. Eggs and J2 of M. incognita were extracted from the whole root system (50dag) and $10 \mathrm{~g}$ of roots (100dag), using COOLEN \&
D'HERDE (1972), and the root population was estimated. The experiment was arranged in a complete randomized design, with two treatments and eight replicates for each sampling date. The data were analyzed by ANOVA, using SAS statistical software (SAS Institute, 2003).

Experiment 2.The aim was to confirm the results obtained in experiment 1 concerning the effect of abamectin on J2 penetration. Freshly extracted inoculum of $\boldsymbol{M}$. incognita was obtained from tomato roots and inoculated (682 eggs and $318 \mathrm{~J} 2$ per pot) into steam-treated substrate as described previously. The germination occurred four days after sowing and the plants were evaluated 1,3 , and $9 \mathrm{dag}$. The juveniles in the roots were stained using acid fuchsin and counted under stereomicroscope. The experiment was arranged in a complete randomized design, with two treatments and eight replicates for each sampling date.

The seed treatment caused a decrease in the $M$. incognita J2 penetration (87.1 and $81.9 \%$, 9dag in the Experiments 1 and 2) as evaluated in experiment 1 (Table 1), result that was confirmed in the experiment 2 (average number of $\mathrm{J} 2$ counted in the roots 1,3 and 9dag: 1.9, 1.9 and 3.5 for treated plants and 5.4; 12.9 and 19.3 for non-treated ones). When abamectin is applied to cotton seed, it concentrates on the seed coat (FASKE \& STARR, 2007) and is highly effective on the soil nematodes in the vicinity. Thereafter, only few $\mathrm{J} 2$ are able to penetrate the roots from treated seeds.

Abamectin is a mixture of two closely related compounds, avermectin B1a and avermectin B1b, produced by the soil fungus Streptomyces avermitilis. Commercial formulations of abamectin are available for foliar spray applications to control insects and mites. The use as a nematicide is limited by its low solubility in water, tightly binding to soil particles and vulnerability to microbial degradation (WISLOCKI et al., 1989). However, it proved to be effective when applied in close proximity to nematodes. Using an in vitro assay of nematode mobility, LD50 value of $1.56 \mu \mathrm{g}$ $\mathrm{mL}^{-1}$ was calculated for $\boldsymbol{M}$. incognita based on $2 \mathrm{~h}$ exposure (FASKE \& STARR, 2006).

In both experiments, only infective juveniles were found at 3 and $9 \mathrm{dag}$. The post infection development of juveniles was not affected by abamectin, as $94 \%$ of juveniles found within the roots from treated seeds at $15 \mathrm{dag}$ were swollen forms, a value very close to the $90 \%$ obtained from roots of non-treated seeds (data not shown). Such result corroborates that abamectin is not taken up from soil into plants (WISLOCKI et al., 1989). Lower colonization and reproduction of $\boldsymbol{M}$. incognita were attained in cotton plants from treated seeds in experiment 1 (Table 1). Roots from treated seeds were clearly less galled than from non-treated seeds. These results were likely indirect effects, considering that the population of $\boldsymbol{M}$. 
Table 1 - Effect of the seed treatment with abamectin $\left(150 \mu \mathrm{g} \operatorname{seed}^{-1}\right)$ on the penetration $(3,9$ and 15 days after germination, dag), colonization (27dag) and reproduction (50 and 100dag) of Meloidogyne incognita. Experiment 1.

\begin{tabular}{|c|c|c|c|c|c|c|c|c|c|}
\hline & 3 dag & 9dag & $15 \mathrm{dag}$ & \multicolumn{2}{|c|}{-----------27dag----------- } & \multicolumn{2}{|c|}{-----------50dag----------- } & \multicolumn{2}{|c|}{---------100 dag--------- } \\
\hline & \multicolumn{3}{|c|}{ Number of $\mathrm{J} 2^{1}$} & galls & Egg masses & $\mathrm{ng}^{2}$ & $\mathrm{RF}^{3}$ & ng & RF \\
\hline Treated & $0.1 \mathrm{a}$ & $11.1 \mathrm{a}$ & $9.6 \mathrm{a}$ & $41 \mathrm{a}$ & $34 \mathrm{a}$ & $1,353 \mathrm{a}$ & $3.2 \mathrm{a}$ & $2,702 \mathrm{a}$ & $69.8 \mathrm{a}$ \\
\hline Non-treated & $18.1 \mathrm{~b}$ & $86.1 \mathrm{~b}$ & $88.2 b$ & $140 \mathrm{~b}$ & $136 b$ & $8,763 b$ & $43.0 \mathrm{~b}$ & $12,342 b$ & $344.0 \mathrm{~b}$ \\
\hline
\end{tabular}

${ }^{1} \mathrm{~J} 2$ : second stage juveniles;

${ }^{2}$ ng: Number of J2 and eggs per gram fresh root;

${ }^{3} \mathrm{RF}$ : reproduction factor.

incognita was diminished by abamectin and consequently fewer $\mathrm{J} 2$ were able to penetrate and initiate colonization in the roots. After infection, population increased sharply even more in cotton plants from treated seeds: between 50 and $100 \mathrm{dag}, \boldsymbol{M}$. incognita population built up 22-fold in plants from treated and 8 -fold in plants from non-treated seeds. Probably healthier cotton roots from treated seeds provided more suitable food source for the nematodes.

The results obtained were congruent with the data provided by MONFORT et al. (2006), who demonstrated that root galling was less severe and nematode reproduction was lower in cotton plants from seed treated with $10,50,75$ and $100 \mu \mathrm{g}$ of abamectin per seed, at 45 days after cotton sowing. However, in another greenhouse trial (FASKE \& STARR, 2007), seed treatment $(150 \mu \mathrm{g}$ per seed) did not reduced galling or nematode reproduction, at 21,28 and 35 days after cotton sowing. The majority of abamectin applied remains on the seed coat (FASKE \& STARR, 2007), and it seems that the seed deposition next to the inoculation site, as used in the experiments here described, improved the efficiency of the treatment. As the roots grow out beyond the soil volume effectively protected by abamectin, the living nematodes are able to infect and colonize them. The relative success in reducing nematode penetration, as demonstrated in the experiments, confirmed that seed treatment with abamectin is a valuable tool in nematode management in cotton culture. Abamectin seed treatment has allowed variable results in suppressing M. incognita in cotton fields (MONFORT et al., 2006). This limitation may be overcome by the adoption of a measure to compensate the immobility of abamectin in soil, eg the concomitant application of soluble nematicides, which reduces nematode population not affected by abamectin. Therefore, it is expected that rather than a substitute to soluble nematicides, seed treatment with abamectin might actually be viewed as a complementary method designed to reduce the total amount of nematicide applied on the ground.

\section{REFERENCES}

ASMUS, G.L.; INOMOTO, M.M. Manejo de nematoides. In: FREIRE, E.C. Algodão no cerrado brasileiro. Brasília: Associação Brasileira dos Produtores de Algodão, 2007. Cap.15, p. $551-580$.

COOLEN, W.A.; D'HERDE, C.J. A method for the quantitative extraction of nematodes from plant tissue. Ghent: State Nematology and Entomology Research Station, 1972. $77 \mathrm{p}$.

DAYKIN, M.E.; HUSSEY, R.S. Staining and histopathological techniques in nematology. In: BARKER, K.R. et al. An advanced treatise on Meloidogyne. Raleigh: North Carolina State University Graphics, 1985. Cap.3, p.39-48.

FASKE, T.R.; STARR, J.L. Cotton root protection from plantparasitic nematodes by abamectin-treated seed. Journal of Nematology, v.39, n.1, p.27-30, 2007. Available from: <http:/ /fulltext10.fcla.edu/DLData/SN/SN0022300X/0039_001/ 27.pdf $>$. Accessed: Jan. 20, 2010.

FASKE, T.R.; STARR, J.L. Sensitivity of Meloidogyne incognita and Rotylenchulus reniformis to abamectin. Journal of Nematology, v.38, n.2, p.240-244, 2006. Available from: $<$ http://fulltext10.fcla.edu/DLData/SN/SN0022300X/ 0038_002/240.pdf>. Accessed: jan. 20, 2010.

MONFORT, W. S. et al. Potential for site-specific management of Meloidogyne incognita in cotton using soil textural zones. Journal of Nematology, v.39, n.1, p.1-8, 2007. Available from: < http://fulltext10.fcla.edu/DLData/SN/SN0022300X/ 0039 001/1.pdf>. Accessed: Jan. 20, 2010.

MONFORT, W.S. et al. Efficacy of a novel nematicidal seed treatment against Meloidogyne incognita on cotton. Journal of Nematology, v.38, n.2, p.245-249, 2006. Available from: $<$ http://fulltext10.fcla.edu/DLData/SN/SN0022300X/ 0038_002/245.pdf>. Accessed: Jan. 20, 2010.

SAS Institute. SAS system for windows. Version 9.1.3. Cary, 2002-2003. (Programa Computacional)

STARR, J.L. et al. The future of nematode management in cotton. Journal of Nematology, v.39, n.4, p.283-294, 2007. Available from: <http://fulltext10.fcla.edu/DLData/SN/ SN0022300X/0039_004/283.pdf>. Accessed: jan. 20, 2010.

WISLOCKI, P.G. et al. Environmental aspects of abamectin use in crop protection. In: CAMPBELL, W.C. Ivermectin and abamectin. New York: Springer-Verlag, 1989. Cap.13, p.182-200. 